\title{
PETROGÊNESE DE FORMAÇÕES FERRÍFERAS E METAHIDROTERMALITOS DA FORMAÇÃO AIMBÉ, GRUPO GUARINOS (ARQUEANO), GOIÁS
}

\author{
MARCELO GONÇALVES RESENDE \& HARDY JOST
}

\begin{abstract}
PETROGENESIS OF IRON FORMATIONS AND METAHYDROTHERMALITES OF THE AIMBÉ FORMATION, GUARINOS GROUP (ARCHAEAN), GOIÁS. The Airnbe Formation is a stratigraphic unit of the Archaean Guarinos Group (Guarinos greenstone belt, Goiás, Central Brazil) consisting of (I) magnetite- and/or haematite-muscovite iron formations, quartz being absent; (ii) metahydrothermalites representing fossil exhalative centers with preserved vents surrounded by hydrothermal alteration haloes containing tourmaline, chloritoid, magnetite, chlorite, and muscovite, and (iii) minor metaconglomerates and metashales. Tourmaline, chloritoid, magnetite, chlorite, and muscovite were quantitatively analysed in a microprobe to determine compositional variations of mineral species common to different alteration haloes, to the two main facies of the iron formations, and to both, to suport the intepretation of the mineral composition of the protoliths of metahydrothermalites and iron formations. The composition of metamorphic minerals suggest that the metahydrothermalites protoliths were probably composed by variable proportions of kaolinite, diaspore, magnetite, pyrophilite, illite, Na-montmorillonite, while muscovite of the iron formations is interpreted as metamorphosed felsic volcanic ash.
\end{abstract}

Keywords: Iron formations, metahydrothermalites, petrogenesis, Archaean, Goiás

\begin{abstract}
RESUMO A Formação Aimbé é uma unidade estratigráfica do Grupo Guarinos (greenstone belt de Guarinos, Goiás), de idade arqueana e contem (i) formações ferríferas predominantes, com magnetita e/ou hematita e muscovita, sem quartzo, (ii) metahidrotermalitos com condutos circundados por diversas zonas de alteração com turmalina, cloritóide, magnetita, clorita e muscovita, e (iii) locais metaconglomerados e metafolhelhos. Turmalina, cloritóide, magnetita, clorita e muscovita foram analisados em microssonda eletrônica para determinar variações composicionais de espécies minerais comuns aos diferentes halos de alteração, às duas subfácies de formações ferríferas, e a ambos, e suportar a interpretação da composição mineral dos protolitos de metahidrotermalitos e formações ferríferas. A composição química dos minerais metamórficos sugere que os protolitos dos metahidrotermalitos continham proporções variadas de caolinita, diaspora, magnetita, pirofílita, illita, Na-montmorillonita e albita. A muscovita das formações ferríferas é interpretada como produto metamórfico de cinza vulcânica félsica.
\end{abstract}

Palavras-chaves: Formações ferríferas, metahidrotermalitos, petrogênese, Arqueano, Goiás

INTRODUÇÃO Formações ferríferas são pouco freqüentes nas rochas supracrustais arqueanas do tipo greenstone belt da região de Crixás, Goiás (Fig. 1), mas a sua presença tem sido registrada desde os trabalhos pioneiros de Danni \& Ribeiro (1978) e Sabóia (1979). As formações ferríferas ocorrem nas faixas de Pilar de Goiás e Guarinos, mas não foram, ainda, observadas na faixa de Crixás. As ocorrências conhecidas consistem de: (a) depósitos do tipo Algoma, nas fácies óxidos e silicato, intercalados em metakomatiitos e metatoleiítos de Pilar de Goiás (Danni et al. 1986) e Guarinos (lost \& Oliveira 1991); (b) depósitos do tipo Superior, associados a mármores e conglomerados, como os da Seqüência Morro Escuro, na faixa Guarinos (Jost et al. 1989); (c) depósitos do tipo SEDEX, como os da Formação Aimbé, faixa Guarinos (Jost et al. 1994, Resende 1994), e (d) ocorrências de origem incerta, intercaladas em filitos carbonosos do topo das seqüências estratigráficas de Guarinos e Pilar de Goiás (Jost \& Oliveira 1991).

A Formação Aimbé, objeto do presente estudo, é uma subunidade do Grupo Guarinos e cujas características foram inicialmente descritas por Jost \& Oliveira (1991) e complementadas por Resende et al. (1993), Jost et al. (1994), Resende (1994) e Resende \& Jost (1994). A unidade tem cerca de $50 \mathrm{~m}$ de espessura e está exposta, segundo a direção, por aproximadamente $25 \mathrm{~km}$ e consiste de (i) formações ferríferas dominantes, com magnetita e/ou hematita e muscovita intersticial ou em bandas, e ausência de quartzo, (ii) lentes de metahidrotermalitos e (iii) lentes de metaconglomerados e metafolhelhos. A presença de metahidrotermalitos e a estranha associação mineral das formações ferríferas motivou uma investigação mais detalhada da composição das espécies minerais metamórficas comuns às rochas dos diferentes halos de alteração hidrotermal, às subfácies de formações ferríferas e a ambos, visando identificar variações composicionais dos minerais metamórficos dos dois ambientes e suportar a interpretação da composição mineral dos protolitos de metahidrotermalitos e formações ferríferas.

ESTRATIGRAFIA E ESTRUTURA As rochas supracrustais do greenstone belt de Guarinos (Fig. 2) estão reunidas no Grupo Guarinos (Jost \& Oliveira 1991). A seção inferior do Grupo é constituída por rochas metavulcânicas que, da base para o topo, compreendem metakomatiitos (Formação Serra do Cotovelo), sotopostos a metabasaltos toleiíticos (Formação Serra Azul), ambos com intercalações de formações ferríferas. A seção superior é metasedimentar e, da base para o topo, compreende: (a) quartzo-clorita xistos, comumente rítmicos da Formação São Patricinho, em parte lateralmente dispostos aos metabasaltos da Formação Serra Azul; (b) formações ferríferas, metahidrotermalitos, metaconglomerados e metafolhelhos da Formação Aimbé, e (c) metapelitos, em geral carbonosos, com raras intercalações de metachert, formações ferríferas e manganesíferas, da Formação Cabaçal.

As paragêneses minerais de metamorfismo regional em metabasaltos e metapelitos são compatíveis com as condições da fácies xisto verde. A foliação metamórfíca resultante é paralela ao acamamento original. A variação da atitude de ambos indica que as unidades mapeadas descrevem, na 


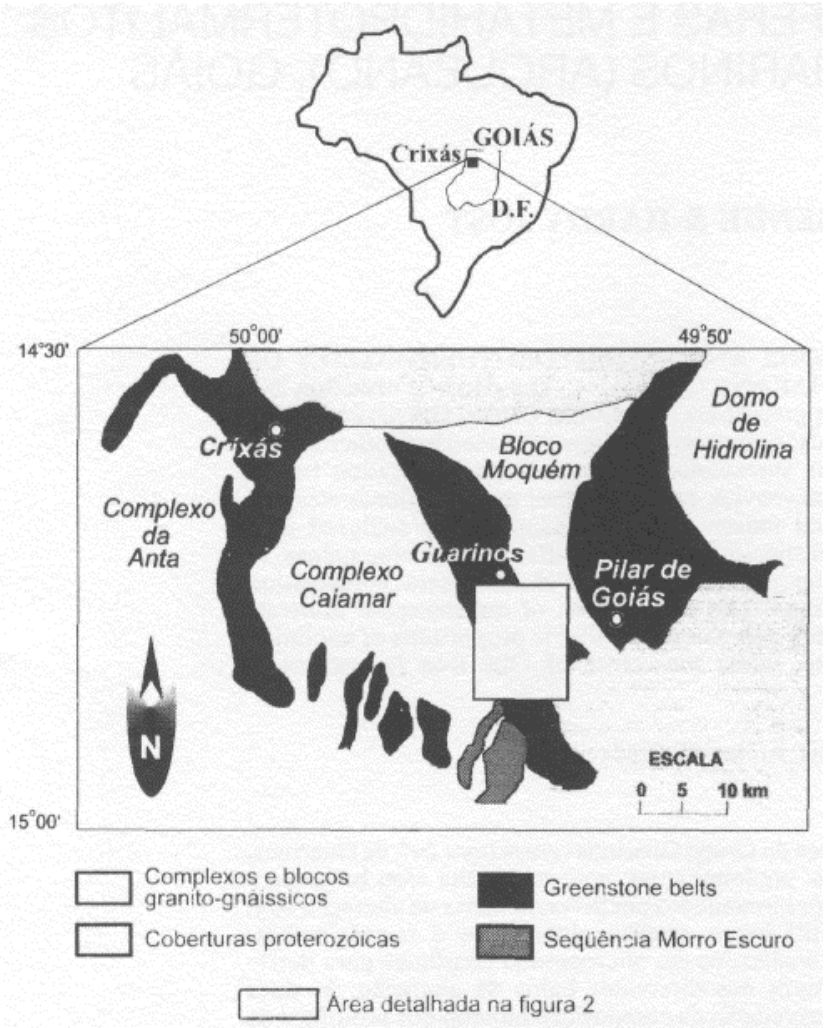

Figura 1 - Localização geográfica do greenstone belt de Guannos, Goiás

Figure 1 - Geographical location of the Guarinos greenstone belt, Goiás, Central Brazil

metade norte da área estudada, um antiforme inverso cuja superfície axial tem atitude média $\mathrm{N} 30^{\circ} \mathrm{W}, 35^{\circ} \mathrm{SW}$. Na metade sul, essa estrutura se bifurca (Fig. 2) para sul como antiforme simétrico e normal, de superfície axial N-S e caimento médio de $10^{\circ} \mathrm{S}$, e para sudeste, como antiforme assimétrico e inverso de superfície axial média com atitude $\mathrm{N} 70^{\circ} \mathrm{W}, 45^{\circ} \mathrm{SW}$ e caimento médio de $15^{\circ} \mathrm{SE}$.

Estruturas primárias reliquiares, tais como laminação e estratificação cruzada, estruturas de corte-e-preenchimento e acamamento gradacional em rochas metassedimentares e estruturas em almofada em metabasaltos indicam que a seqüência estratigráfica do Grupo Guarinos está inteiramente invertida. Isto condiz com a localização das unidades mais antigas, como os metakomatiitos da Formação Serra do Cotovelo, em posições estruturais elevadas, em contraste com unidades mais jovens, como os metassedimentos da Formação Cabaçal, situados no núcleo da estrutura.

A Formação Aimbé recobre, a norte, metabasaltos da Formação Serra Azul e, a sul, rochas metassedimentares da Formação São Patricinho, sinalizando que a unidade provavelmente repousa sobre uma discordância. O contato é brusco, por vezes tectônico. Quando brusco, os metabasaltos da Formação Serra Azul e os metassedimentos da Formação São Patricinho mostram, freqüentemente, uma zona com até $2 \mathrm{~m}$ de espessura com cloritóide e sericita, sugerindo que a deposição dos sedimentos da Formação Aimbé foi precedida da alteração do seu substrato. Já o contato com os xistos carbonosos da Formação Cabaçal varia de brusco a rapidamente gradual, quando então a passagem é marcada por um intervalo com até $5 \mathrm{~m}$ de espessura onde se alternam finos leitos de filito carbonoso e formação ferrífera. Os metaconglomerados, metafolhelhos e metahidrotermalitos da base da Formação Aimbé e o contato com os metabasaltos da Formação Serra Azul e as rochas metassedimentares da
Formação São Patricinho situam-se, sempre, em posições estruturais mais elevadas que o contato gradual das formações ferríferas com os metapelitos da Formação Cabaçal, em razão da inversão estratigráfica intepretada a partir de outros critérios.

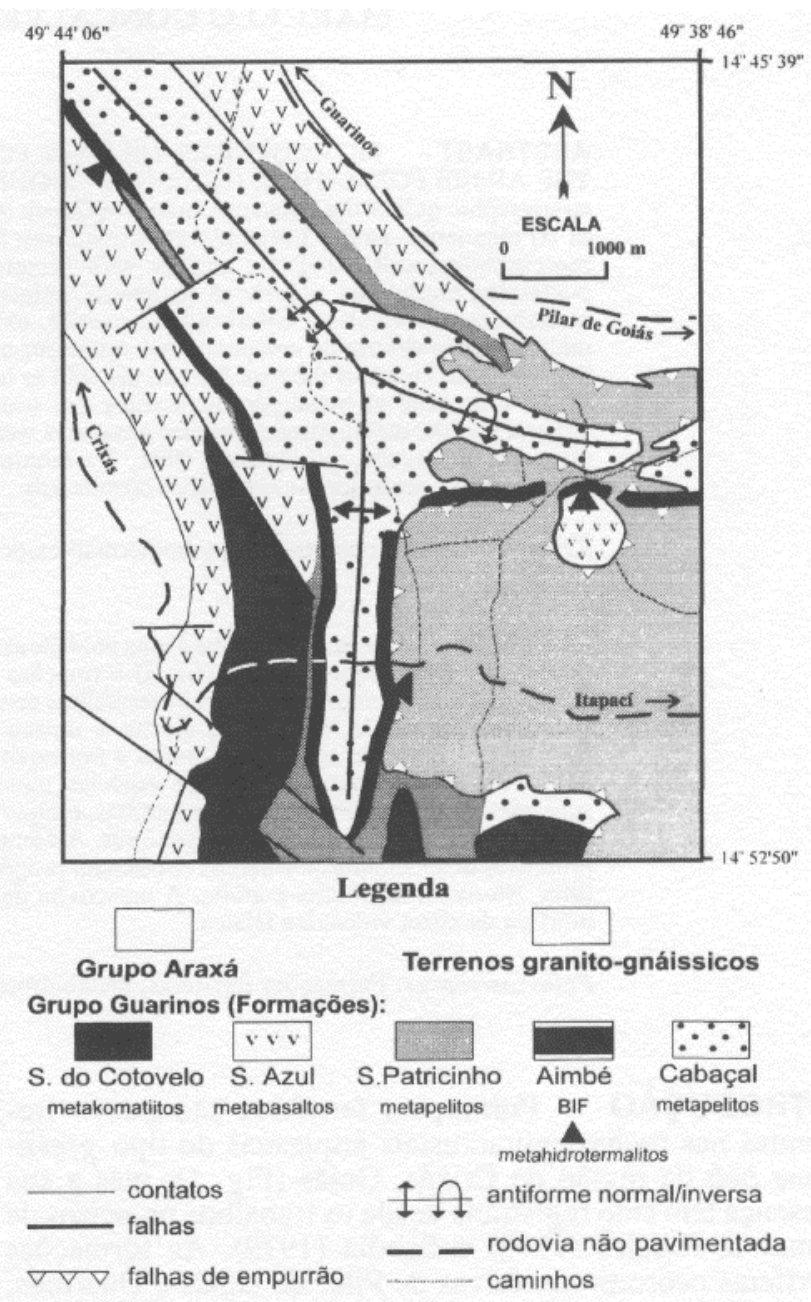

Figura 2 - Mapa geológico da porção centro-sul do greenstone belt de Guannos, mostrando a área de ocorrência da Formação Aimbé

Figure 2 - Geologic map of the central-south part of the Guannos greenstone belt, showing the area of occurrence of the Aimbé Formation

PETROGRAFIA Os litotipos da Formação Aimbé compreendem, em ordem decrescente de abundância, formações ferríferas.. metahidrotermalitos e rochas metassedimentares detríticas. Para efeitos do presente trabalho, os aspectos petrográficos das últimas não serão descritos.

Formações Ferríferas As formações ferríferas (Foto 1) são as rochas características da Formação Aimbé e ocorrem em duas subfácies, sendo uma basal com magnetita e uma de topo com hematita. A sua estrutura pode ser maciça, presente em ambas as subfácies, bandada, dominante na subfácies com magnetita, ou laminada, característica da subfácies com hematita. Laminação e bandamento são dados pela alternância de níveis de espessura milimétrica a centimétrica, ora ricos em magnetita ou hematita, ora em muscovita. Estruturas secundárias tais como dobras de estilos geométricos variados, lineações de estiramento, superfícies S-C e sombras de pressão associadas a porfiroclastos de magnetita ou de hematita, são freqüentes. 


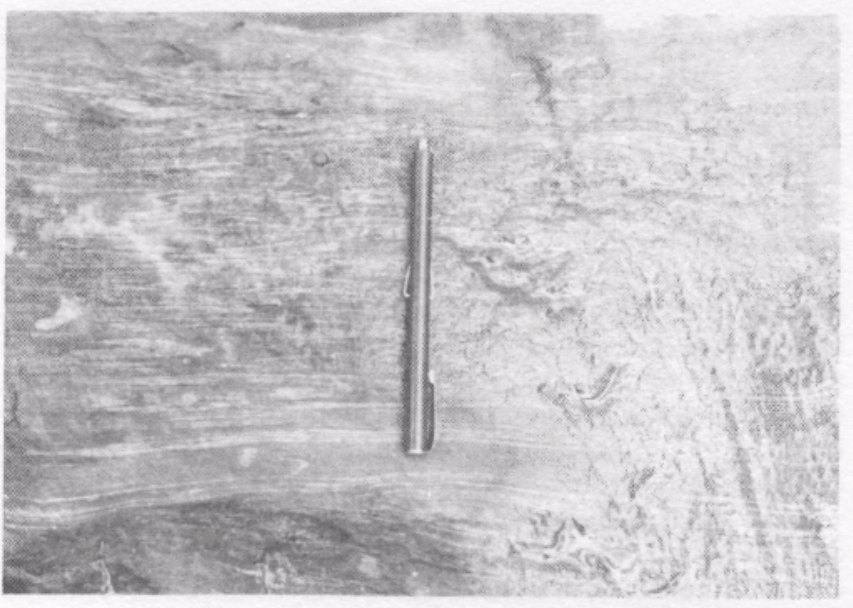

Foto l - Formação Aimbé. Afloramento de formação ferrífera bandada, sub-subfácies magnetita, mostrando a alternância de níveis de magnetita com níveis de muscovita Photo 1 - Aimbé Formation. Outcrop of the magnetite sub-facies banded iron formation showing the alternation of magnetite and muscovite layers

Ao microscópio, as formações ferríferas apresentam texturas granoblástica e lepidoblástica em domínios alternados. Seus constituintes essenciais compreendem magnetita e/ou hematita e muscovita. Quartzo, quando presente, não excede $5 \%$.

Em amostras menos deformadas, a magnetita ocorre em cristais pré-tectônicos comumente euédricos, com diâmetro entre $0,1 \mathrm{~mm}$ até $2 \mathrm{~mm}$. Com o incremento da deformação, os cristais se alongam segundo a foliação, adquirem sombras de pressão com quartzo e muscovita e desenvolvem trilhas de cominuição mecânica, cujos subgrãos podem, por recuperação, formar porfiroblastos sin-tectônicos. Independente de serem pré- ou sin-cinemáticos e do estado de deformação, os cristais de magnetita estão comumente martitizados, sugerindo que a sua oxidação para hematita resulta de alteração superficial.

A hematita é da variedade especularita e, a exemplo da magnetita, também ocorre em cristais pré-tectônicos, geralmente lamelares, euédricos e com comprimento entre 0,1 $\mathrm{mm}$ e $2 \mathrm{~mm}$. Os cristais de especularita estão sempre alinhados segundo uma direção preferencial, independente da orientação dos demais constituintes. $\mathrm{O}$ aumento da deformação também é acompanhado da cominuição mecânica da hematita, em geral com recuperação dos sub-grãos para especularita mais fina.

A muscovita é ora intersticial à magnetita e/ou hematita, ora ocorre em níveis onde predomina. Em ambos casos, o mineral contem diminutas inclusões de magnetita e/ou hematita. Quando intersticial, as palhetas de muscovita são anédricas, de granulação inferior a $0,3 \mathrm{~mm}$ e estão comumente intercrescidas. Já nos níveis onde predomina, a muscovita é euédrica e suas palhetas, raramente intercrescidas, possuem dimensões maiores, variáveis entre 0,2 e $1 \mathrm{~mm}$. Em amostras menos deformadas, a muscovita intersticial não está orientada, mas, nos níveis onde se concentra, está orientada ortogonalmente ao bandamento composicional. Com o aumento da deformação, as palhetas interticiais se agrupam em filetes que contornam porfiroclastos alongados de magnetita e/ou hematita, e, nos níveis mais ricos no mineral, as palhetas estão orientadas segundo uma direção comum, paralela ao bandamento composicional. Amostras com intensa deformação apresentam, comumente, porfiroblastos pós-tectônicos de muscovita, desenvolvidos aleatoriamente sobre a matriz foliada de muscovita.
O quartzo, quando presente, ora é constituinte de sombras de pressão, ora ocorre como diminutos grãos anédricos, disseminados e intercrescidos com muscovita.

Metahidrotermalitos Rochas interpretadas como metahidrotermalitos compreendem associações minerais diversas agrupadas e localizadas na base das formações ferríferas. Três áreas com estas rochas foram, até o presente, identificadas (Fig. 2), as quais se assemelham em geometria, relações de contato com rochas encaixantes, estrutura interna e tipos de rochas, como resumido na figura 3.

A expressão dos corpos com metahidrotermalitos em planta é de uma elipse assimétrica alongada segundo a foliação metamórfica local mais proeminente, com eixos médios menor e maior respectivamente de $50 \mathrm{~m}$ e $200 \mathrm{~m}$. Esses corpos estão, de um lado, engastados em rochas metassedimentares da Formação São Patricinho ou em metabasaltos da Formação Serra Azul, e, no lado oposto, lateralmente interdigitadas com as formações ferríferas.

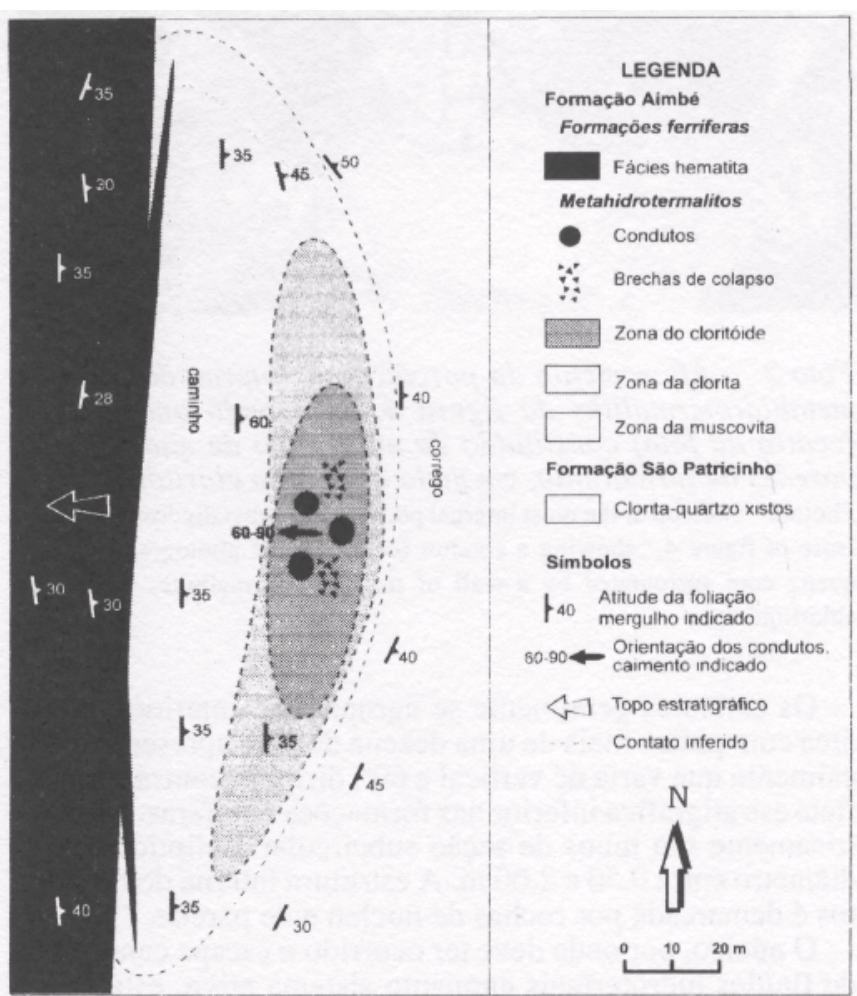

Figura 3-Mapa geológico da lente cie metahidrotermaliios mais meridional da Formação Aimbé, mostrando a natureza concêntrica das diversas zonas em torno dos núcleos com condutos, o seu engaste preferencial no interior de metassedimentos da Formação São Patricinho e sua interdigitação lateral com a base das formações ferríferas. Observar que a orientação dos condutos é contrária à atitude das formações ferríferas. A seqüência estratigráfica está invertida, de modo que a visão do conjunto de condutos e zonas de metahidrotermalitos é de baixo para cima, em direção à superfície de deposição das formações ferríferas Figure 3 - Geologic map of the southernmost metahydrothermalite lense of the Aimbé Formation, showing the alteration haloes concentric around a core with conduits, as well as the partial setting of the zones within metassedimentary rocks of the São Patricinho Formation and, in the oposite side, the partial lateral interfingering of the metahidrothermalites with the lower portions of the iron formations. Observe that the orientation of the conduits is oposite to the attitude of the iron formations. The sequence is overturned so that the plan view of the conduits and metahidrothermal haloes is from below and toward the depositional surface of the iron formations 
A estrutura interna dos corpos de metahidrotermalitos é zonada. Geralmente consistem de um núcleo contendo relíquias de estruturas e rochas de condutos fossilizados de canalização das soluções hidrotermais, envelopado por três zonas com metahidrotermalitos. Cada zona é caracterizada por associações próprias de aluminossilicatos metamórficos e, de acordo com o mineral predominante, compreendem as zonas do cloritóide, da clorita e da muscovita, respectivamente do núcleo para a periferia. Os condutos fossilizados situam-se na zona do cloritóide.

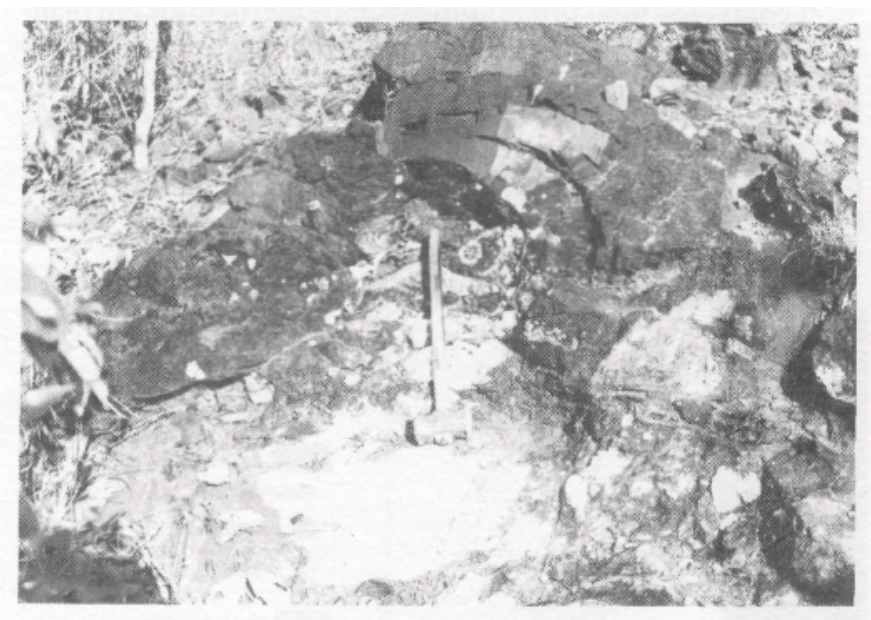

Foto 2 -Afloramento da porção mais interna da lente de metahidrotermalitos da figura 4, mostrando um conduto (centro da foto) constituído de um núcleo de quartzo com paredes de turmalinito, em meio à zona do cloritóide Photo 2- Outcrop of the most internal portion of the metahydrothermalites lense of figure 4, showing a conduit (centre of the photograph) with a quartz core surrounded by a wall of massive tourmalinite, within the chloritoid zone

Os condutos geralmente se agrupam no interior de uma área com pouco mais de uma dezena de $\mathrm{m}^{2}$ e apresentam um caimento que varia de vertical a $60^{\circ}$, dirigido contra a superfície estratigráfica inferior das formações ferríferas. Geometricamente são tubos de seção subcircular a eliptica e com diâmetro entre 0.50 e $2.00 \mathrm{~m}$. A estrutura interna dos condutos é demarcada por rochas de núcleo e de parede.

O núcleo, por onde deve ter ocorrido o escape canalizado de fluídos hidrotermais enquanto sistema ativo, está, hoje, obstruído por quartzo leitoso sacaroidal. As paredes tềm espessura entre 20 e $60 \mathrm{~cm}$ e consistem de turmalinito, cujas propriedades texturais e composicionais permitem subdividi-lo em três sub-zonas. A mais interna, situada junto ao núcleo de quartzo, tem espessura centimétrica e é um agregado de agulhas euédricas milimétricas de schorlita. A intermediária, bem exposta na figura 5 , tem espessura entre $10 \mathrm{e}$ $20 \mathrm{~cm}$ e consiste de um turmalinito preto, de aspecto afanítico, estrutura radiada e que, ao microscópio, é maciço a ligeiramente bandado e composto por um agregado microcristalino de turmalina esferóide, localmente com quartzo intersticial. A zona externa está parcialmente superimposta à do cloritóide em cerca de 1-2 $\mathrm{cm}$ e, ao microscópio, mostra turmalina crescida sobre muscovita, cloritóide e magnetita, indicando que, nesta zona, a turmalina é metamórfica, em contraste com as demais, onde o mineral, se não está parcialmente recristalizado, pode ser primário.

A zona do cloritóide tem largura média de $10 \mathrm{~m}$ e seu contato com o turmalinito das paredes dos condutos é, originalmente, brusco. Contudo, a presença de turmalina metamórfica no contato sugere que o contato passou a ser rapidamente gradual por metamorfismo. O litotipo diagnóstico desta zona é uma rocha de cor verde-escuro, granulação grossa a média, com fenoblastos euédricos de cloritóide de até $1 \mathrm{~cm}$ de comprimento, imersos em uma matriz mais fina, foliada ou não. Em lâmina delgada a rocha mostra textura lepidoblástica, localmente porfiroblástica, e é composta por clorita e cloritóide, com muscovita, magnetita e turmalina acessórias, localmente também stilpnomelano e ilmenita. Em amostras com foliação ausente ou incipiente, todos os constituintes minerais cresceram desordenadamente, indicando recristalização sob regime estático. Com o incremento da deformação, todos os minerais da zona do cloritóide estão rotacionados, encurvados, estirados e mecanicamente cominuídos, indicando que os termos foliados resultam por cisalhamento dos não foliados.

Nas proximidades dos condutos, a rocha da zona do cloritóide pode conter fragmentos angulosos, milimétricos a decimétricos de turmalinito microcristalino, provavelmente representando brechas de colapso das paredes destes.

A zona da clorita tem largura variável entre 1 e $20 \mathrm{~m}$ e o contato com a do cloritóide é gradacional, como sugere a progressiva diminuição da quantidade de cloritóide e aumento na de muscovita. A rocha típica desta zona é um clorita xisto verde claro, localmente com lentes milimétricas de quartzo. Ao microscópio, a rocha mostra uma textura lepidoblástica, localmente granoblástica e seus constituintes essenciais compreendem clorita e muscovita, com magnetita sub-essencial à acessória.

O halo mais externo das lentes de metahidrotermalitos é um muscovita xisto cinza-claro de granulação fina, textura lepidoblástica e pode conter até $90 \%$ de muscovita, com turmalina e magnetita acessórias.

QUÍMICA MINERAL Amostras representativas de formações ferríferas e de metahidrotermalitos da Formação Aimbé foram preparadas para análise química de espécies minerais por microssonda eletrônica do Instituto de Geociências da Universidade de Brasília. Foram empregadas 6 seções polidas de formações ferríferas, representando diferentes posições estratigráficas, 3 lâminas representativas das zonas do cloritóide, da clorita e da muscovita, e 1 lâmina da porção externa da parede de um conduto, contendo tanto turmalina microcristalina quanto a de substituição de cloritóide, muscovita e magnetita. As análises foram pontuais e quantitativas (WDS), em grãos minerais previamente escolhidos por estudos petrográficos, totalizando 183 pontos de análise completa para óxidos de elementos maiores e menores. Eventuais variações composicionais internas de cada espécie mineral foram aferidas pela análise de no mínimo três pontos por grão, localizados respectivamente no centro, na periferia e em posição intermediária. Os resultados analíticos, reduzidos às respecivas médias aritméticas, constam da Tabela I.

Três variedades texturais de turmalina foram analisadas, compreendendo a de turmalinito maciço das paredes dos condutos, a que substitui silicatos e a que substitui óxidos. O fechamento analítico oscila entre $89-90 \%$, uma vez que Boro não é detectado pela microssonda. As três variedades texturais, no entanto, se resumem a dois tipos composicionais, cujas fórmulas estruturais, como proposto por Rosemberg \& Foit (1985) e Deer, Howie \& Zussman (1992), compreendem:

Tipo 1 - $\left(\mathrm{Na}_{0.25-0.49} \mathrm{Ca}_{0-0.07} \mathrm{~K}_{0-0.02}\right)\left(\mathrm{Mg}_{0.14-0.49} \mathrm{Fe}^{+2}\right.$ 1.92-2.01 $^{\mathrm{Al}}$ 1.34-1.86) $\mathrm{Al}_{6} \mathrm{Si}_{5.90-5.98} \mathrm{O}_{18}\left(\mathrm{BO}_{3}\right)_{3} \mathrm{O}_{3}$

Tipo 2 - $\left(\mathrm{Na}_{0.54-0.65} \mathrm{Ca}_{0.01-0.08} \mathrm{~K}_{0-0.02}\right)\left(\mathrm{Mg}_{0.84-0.95} \mathrm{Fe}^{+2}{ }_{1.62-1.87} \mathrm{Al}\right.$ 1.21-1.42) $\mathrm{Al}_{6} \mathrm{Si}_{5.90-5.99} \mathrm{O}_{18}\left(\mathrm{BO}_{3}\right)_{3} \mathrm{O}_{3}$

A turmalina do Tipo 1 é representativa de turmalinito maciço das paredes dos condutos e a do Tipo 2 é de substi- 
Tabela I - Formação Aimbé. Média aritmética de análises química de óxidos dosados por microssonda eletrônica em (i) iurmalina, cloritóide e clorita de metahidrotermalitos; (ii) muscovita de metahidrotermaUtos e das fades magnetita e hematita das formações ferríferas, (iii) magnetita de metahidrotermaUtos e formações ferríferas (fades magnetita), e (vi) hematita das fades magnetita e hematita das formações ferriferas. $N \mathrm{w}$ número de análises

Table I - Aimbé Formation. Arithmetic mean of oxides determined by microprobe analysis in (i) turmaline, chloritóid, and chlorite of the metahydrothermalites; (ii) muscovite of the metahydroteermalites and of the magnetite and haematite facies of the iron formations; (iii) magnetite of the metahydrothermalites and of the iron formations (magnetite facies), and (vi) haematita of the magnetite and haematite of the facies of the iron formations.

$\mathrm{N}=$ number of averaged analysis

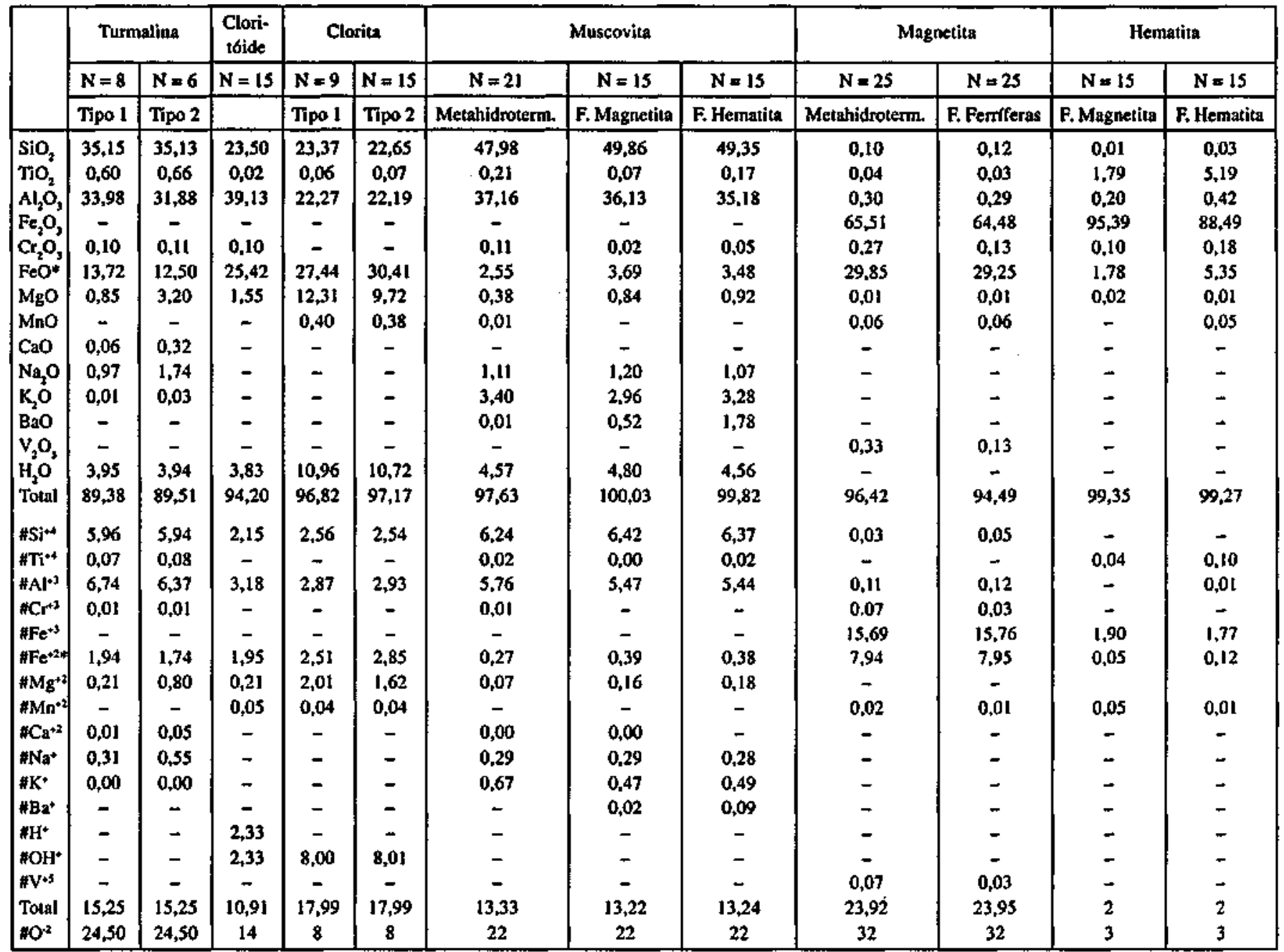

tuição. Ambos tipos pertencem à série Dravita-Schorlita e situam-se próximo ao termo ferrífero Schorlita-Buergerita. Como mostram as fórmulas estruturais e os dados da Tabela I, a turmalina do Tipo 1 difere nas proporções um pouco maiores de $\mathrm{A}_{2} \mathrm{O}_{3}$ e $\mathrm{FeO}^{*}$ e muito menores de $\mathrm{MgO}, \mathrm{CaO}$ e $\mathrm{Na}_{2} \mathrm{O}$, comparativamente a do Tipo 2, como esperado pelas respectivas relações texturais.

O cloritóide não apresenta variações composicionais do centro para periferia de um mesmo cristal, bem como entre cristais das zonas onde ocorre. O mineral é, portanto, interna e faciologicamente homogêneo e sua fórmula estrutural, como proposta por Banfield, et al. (1989), é:

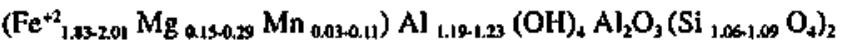

a qual, combinada com a composição média mostrada na Tabela I, registra que o mineral pertence ao termo rico em $\mathrm{FeO}$, relativamente ao $\mathrm{MgO}$.

A clorita compreende dois tipos composicionais (Tab. I). Um é representado pela clorita da zona do cloritóide e outro da zona da clorita. As respectivas fórmulas estruturais são:

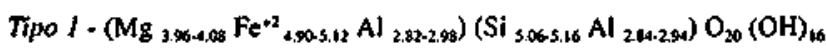

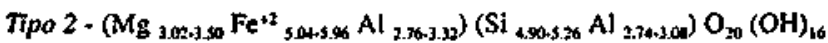

Segundo a classificação de Foster (1962), ambas caem no campo da ripidolita, intermediária na solução sólida sheradanita-turingita. As fórmulas estruturais, os dados da Tabela I e as figuras $4 \mathrm{a}$ e $4 \mathrm{~b}$ mostram que a primeira é mais rica em $\mathrm{MgO}$ e $\mathrm{SiO}_{2}$, e pobre em $\mathrm{FeO}^{*}$, ocorrendo o inverso com a segunda.

A diferença composicional da clorita da zona do cloritóide e da zona da clorita sugere que os minerais precursores formaram-se sob condições hidrotermais diferentes. É provável que a primeira reflita condições hidrotermais de lixiviação do ferro e álcalis, menos intensa na zona da clorita.

A muscovita (Tab. I) dos metahidrotermalitos tem uma fórmula estrutural expressa por:

$\left(\mathrm{K}_{0,62-1,00} \mathrm{Na}{ }_{0.25-0,39} \mathrm{Ca}_{00.04}\right)\left(\mathrm{Al}{ }_{3.90-4.04} \mathrm{Fe}^{+2}\right.$ 0.24-0.28 $\mathrm{Ti}_{0.01-0.02}$ $\left.\mathrm{Cr}_{0,01-0.03} \mathrm{Mg}_{0,03-1,09}\right)\left(\mathrm{Si}_{6,11-6.24}^{0.0 .01} \mathrm{Al}_{1.74-1.89}\right) \mathrm{O}_{20}(\mathrm{OH}, \mathrm{F})_{4}$ 

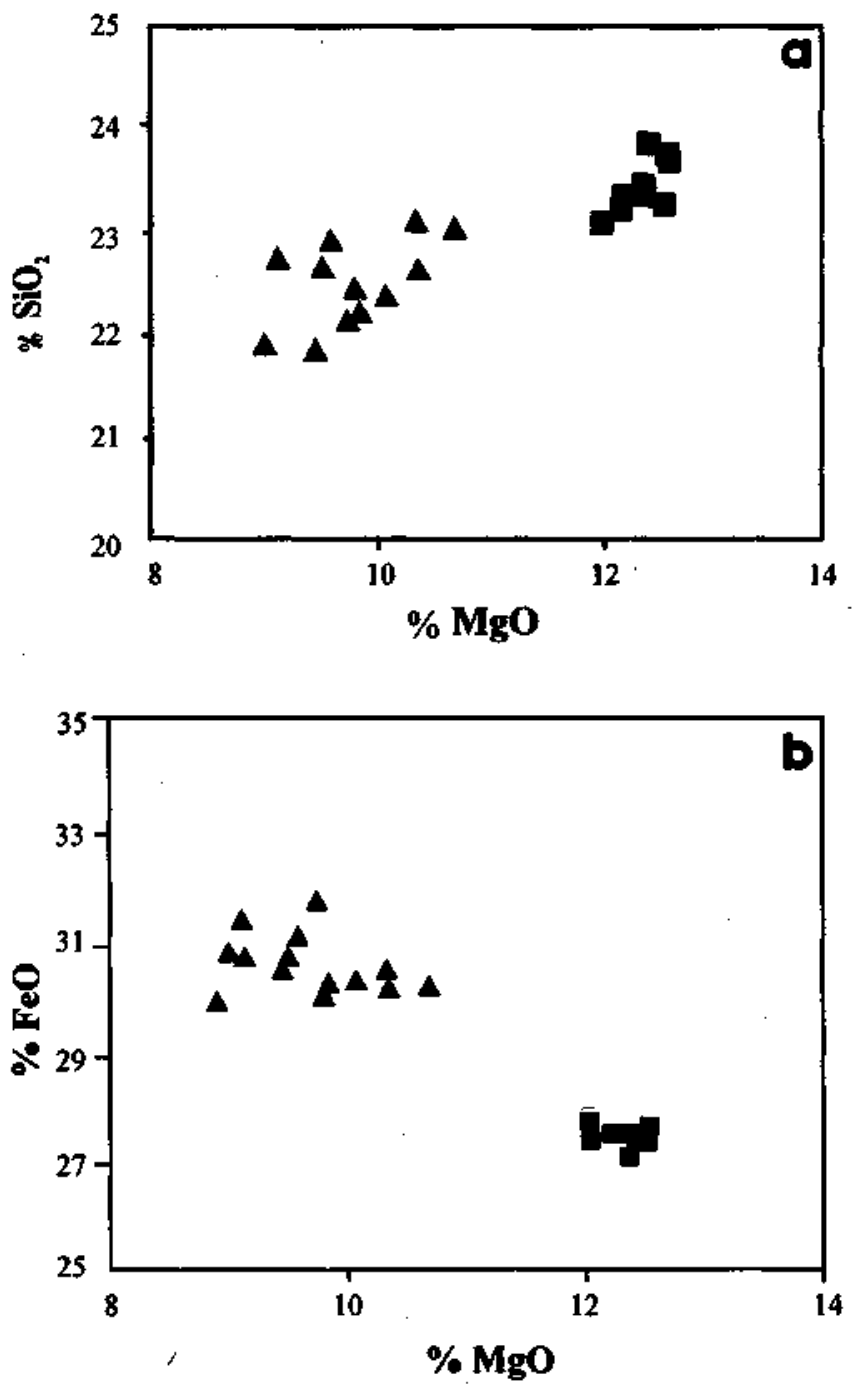

Figura 4 - (a) Diagramas $\mathrm{MgO}_{\mathrm{O}}$ versus $\mathrm{SiO}_{2}$ e (b) $\mathrm{MgO}$ versus FeO de clorita da zona da clorita (A) e da zona do cloritóide (1) dos metahidrotermalitos da Formaçāo Aimbe, mostrando que a primeira é mais rica em $\mathrm{FeO}$ e mais pobre em $\mathrm{SiO}_{2}$ que a segunda

Figure 4 - (a) $\mathrm{MgO}$ versus $\mathrm{SiO}_{2}$ and (b) $\mathrm{MgO}$ versus $\mathrm{FeO}$ diagrams for chlorite of the chlorite zone (A) and of the chloritoid zone $(D)$ of metahydrotermalites of the Aimbe Formation, showing that the former is richer in $\mathrm{FeO}$ and poorer in $\mathrm{SiO}_{2}$ than the later

a qual contrasta com a de ambas fácies das formaçoes fentiferas, cuja fórmula estrutural é:

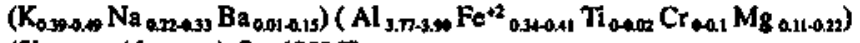

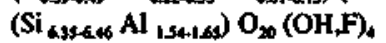

A composição média (Tab. I) e as fórmulas estruturais mostram que a muscovita das formações ferríferas é mais rica em $\mathrm{SiO}_{2}, \mathrm{MgO}, \mathrm{FeO}^{*}$ e $\mathrm{BaO}$ que a dos metahidrotermalitos, mais rica em $\mathrm{K}_{2} \mathrm{O}, \mathrm{Al}_{2} \mathrm{O}_{3}$ e $\mathrm{Cr}_{2} \mathrm{O}_{3}$. Os diagramas das figuras 5 a e 5 b distinguem bem as duas variedades em base às proporções de $\mathrm{SiO}_{2} \times \mathrm{K}_{2} \mathrm{O}$ e de $\mathrm{MgO} \times \mathrm{FeO}$, pelo agrupamento das amostras em dois campos, ambos com correlação negativa de $\mathrm{K}_{2} \mathrm{O}$ com $\mathrm{SiO}_{2}$ e positiva $\mathrm{FeO}$ com $\mathrm{MgO}$.

As fórmulas estruturais também mostram que, em ambos casos, o Na substitui o $\mathrm{K}$ em quantidades consideráveis, indicando significativas proporções da molécula de paragonita na estrutura da muscovita. No sítio octaédrico, o
Al está sendo substituído por Fe, subordinadamente $\mathrm{Mg}$, Ti e Cr.

A feição química mais proeminente da muscovita das formaç̃es ferríferas é a variação dos teores em $\mathrm{BaO}$ (Tab. I) da subfácies com magnetita, onde o oxido ocorre em até $0,8 \%$, para a hematita, onde alcança até $2.5 \%$. A figura $5 \mathrm{c}$ mostra que a correlação de $\mathrm{TiO}_{2}$ com $\mathrm{BaO}$ é negativa na muscovita da subfácies com magnetita, mas é invariante na muscovita da subfácies com hematita, por sua vez mais rica em ambos óxidos. Isto indica que o Ti pode estar substituindo o Al na estrutura da muscovita da subfácies hematita. Nos metahidrotermalitos, o $\mathrm{BaO}$, quando presente, ocorre apenas em traço.

A composição química da magnetita da Formação Aimbé permite atribuir-lhe uma fórmula estrutural dada por :

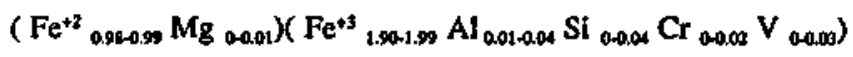

onde as proporções de $\mathrm{Fe}^{+2}$ e $\mathrm{Fe}^{+3}$, quando se trata de óxidos, são automaticamente geradas pela microssonda. A Tabela I mostra que não há diferenças substanciais entre a magnetita dos metahidrotermalitos e das formações ferríferas. Pequenas proporções de $\mathrm{Si}, \mathrm{Al}, \mathrm{Cr}$ e $\mathrm{V}$ substituem $\mathrm{Fe}^{*^{3}}$, indicando tratar-se de magnetita sem solução sólida com outros espinélios. O fechamento analítico pode estar associado à martitização da magnetita, alterando o balanço de cargas entre $\mathrm{Fe}^{+2} \mathrm{e} \mathrm{Fe}^{+3}$.

A composição da hematita (Tab. I) das formações ferríferas da Formação Aimbé admite duas fórmulas estruturais. $\mathrm{Na}$ subfácies magnetita, o mineral tem fórmula:

$\left(\mathrm{Fe}^{+3}{ }_{1,87-1.99} \mathrm{Fe}^{+2}{ }_{0,0.07} \mathrm{Ti}_{0,0.06} \mathrm{Al}_{000.01}\right)_{2} \mathrm{O}_{3}$

enquanto na subfácies hematita, onde o mineral está em equilíbrio com espinélio, a fórmula é:

$\left(\mathrm{Fe}^{+3}{ }_{1.66-1.81} \mathrm{Fe}^{+2}{ }_{0.09-0.17} \mathrm{Ti}_{0.09-0.16} \mathrm{Cr}_{0.0 .01} \mathrm{Al}_{0.01-0.04}\right)_{2} \mathrm{O}_{3}$

e registra proporções ligeiramente menores de $\mathrm{Fe}^{+3}$, maiores de $\mathrm{Fe}^{+2}$, $\mathrm{T} 1$ e $\mathrm{Al}$ e presença de $\mathrm{Cr}$, relativamente à primeira. Dentre os óxidos, a hematita é o mineral mais sensível a variações composicipnais e, como mostra a figura $6,0 \mathrm{TiO}_{2}$ se correlaciona positivamente com $\mathrm{FeO}$, com enriquecimento gradual de ambos óxidos de uma subfácies para outra.

PETROGÊNESE Metahidrotermalitos A petrogênese dos metahidrotermalitos da Formação Aimbé pode ser discutida a partir de dois estágios principais: (a) estágio hidrotermal, durante a qual formaram-se as paragêneses minerais a partir de rochas do substrato devido à percolação de fluídos hidrotermais, e (b) estágio de metamorfismo, quando houve o re-equilíbrio dos produtos de alteração hidrotermal durante a deformação.

Os condutos exalativos fossilizados sugerem que o fluxo do sistema hidrotermal, próximo da superfície, foi canalizado em espaços abertos. Entretanto, a sistemática associação dos condutos com amplas zonas de alteração hidrotermal também sugerem que o sistema foi suficientemente pressurizado para a sua difusão para o interior das rochas encaixantes, expandindo lateralmente a alteração. As dimensões dos condutos e o volume das formações ferríferas sugerem, no entanto, que o fluxo foi preferencialmente canalizado.

Dados geoquímicos de elementos maiores, menores e em traço de rocha total (Resende et al. 1993, Resende 1994) mostram que os metahidrotermalitos são ricos em $\mathrm{Fe}, \mathrm{Mg}$, $\mathrm{Cr}$, Ni e outros elementos pesados, sugerindo que o sistema hidrotermal percolou uma seção crustal composta por rochas máficas e ultramáficas, e sedimentares correlatas, subjacente à Formação Aimbé. A intensidade e a amplitude 

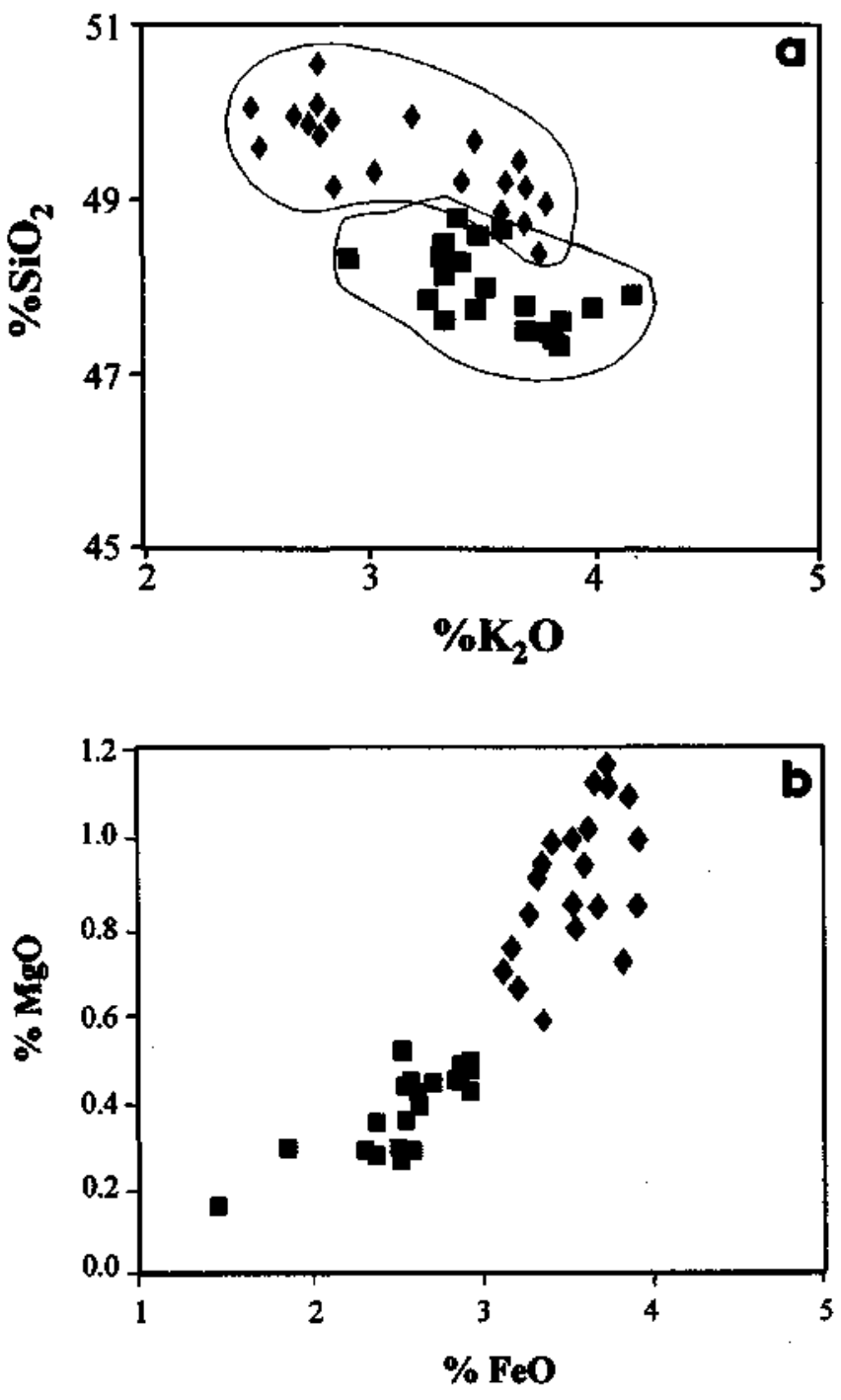

da alteração hidrotermal indicam que a nucleação das fases minerais resultantes de alteração hidrotermal foi induzida por prolongada residência dos fluidos e elevada razão fluído/rocha.

A associação clorita-corrensita-esmectita-illita é típica de alteração hidrotermal do substrato dos oceanos modernos (Hillier 1993) e onde a clorita se forma preferencialmente na, ou próximo da, interface fluido exalativo/água do mar, a partir de reações envolvendo $\mathrm{Fe}, \mathrm{Mg}$ e $\mathrm{SiO}_{2}$ de ambos meios (Caritat 1993). Assim, a clorita hidrotermal precursora das espécies metamórficas encontradas nas zonas do cloritóide e da clorita nos exemplos estudados, pode ser explicada mediante a formação direta de clorita durante a alteração ou por reações envolvendo esmectita da série saponita-Fe-saponita.

A ausência de quartzo nos metahidrotermalitos com cloritóide sugere que a formação de cloritóide nas rochas estudadas pode ser justificada, como sugere Ganguli (1969), por reações entre minerais hidrotermais originais, tais como:

Caolinita + Diásporo + Magnetita $=>$ Cloritóide $+\mathrm{H}_{2} \mathrm{O}+\mathrm{O}_{2}$ ou

Pirofilita + Diásporo + Magnetita $=>$ Cloritóide $+\mathrm{H}_{2} \mathrm{O}+\mathrm{O}_{2}$

o que implica em que os protolitos de alteração hidrotermal da zona do cloritóide, além de peraluminosos, já poderiam conter magnetita.

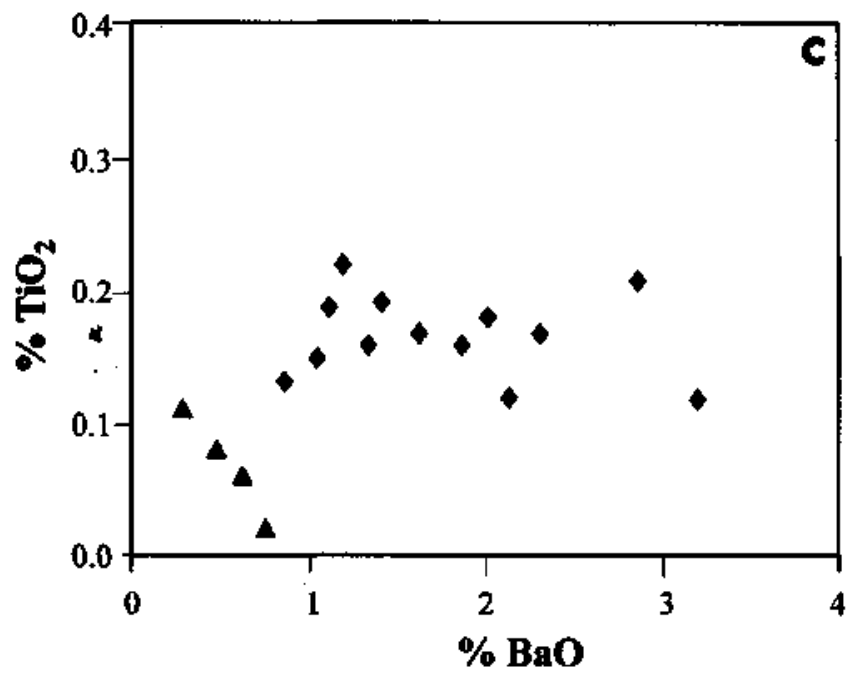

Figura 5-(a) Diagramas $\mathrm{K}_{2} \mathrm{O}$ versus $\mathrm{SiO}_{7}$ e (b) $\mathrm{FeO}$ versus $M g O$ de muscovita das formaçes ferriferas (\$) $e$ dos metahidrotermalitos (प) da Formação Aimbé, mostrando os trends de variacto e gue a muscovita dos primeiros $e$ mais rica em $\mathrm{K}_{2} \mathrm{O}, \mathrm{MgO}_{\mathrm{g}} \mathrm{FeO}$ que a segunda* (c) diagrama BaO versus $\mathrm{TiO}_{2}$ de muscovila das sub-facies magnetita (A) $e$ hematita (†), mostrando que a muscovita dos últimos é mais enriquecida em $\mathrm{BaO}$ e $\mathrm{TiO}_{2}$ e que a correlaçāo entre esses elementos e linear negativa na primeira e aproximadamente invariante na segunda

Figure $\mathrm{S}-$ (a) $\mathrm{K}_{1} \mathrm{O}$ versus $\mathrm{SiO}_{2}$ and (b) FeO versus $\mathrm{MgO}$ diagrams for muscovile of the iron formations ( $\rightarrow$ ) and metahydrothermalites $(D)$ of the Aimbe Fornation, showing variation trends and that muscovile of the formers is richer in $\mathrm{K}_{2} \mathrm{O}, \mathrm{MgO}$ and $\mathrm{FeO}$ than of the later; (c) BaO versus $\mathrm{TiO}_{2}$ diagram for muscovite of the magnetite $(\Delta)$ ard haemalite $(\uparrow)$ subfacies, showing that muscovite of the later is richer in $\mathrm{BaO}$ and $\mathrm{TiO}_{2}$ and that the elements have a negative linear correlation in the former and is almost unvariant in the later

Quanto à muscovita, Velde (1985) mostra que argilas potássicas de alteração hidrotermal, tais como a ilita, podem ser precurssoras de muscovita. As elevadas proporções de $\mathrm{Na}$ no sítio do $\mathrm{K}$ da muscovita dos metahidrotermalitos indica que a mesma pertence à série muscovita-paragonita. A solução sólida illita-bramalita poderia justificar a presença de Sódio nos protolitos e a muscovita metamórfica dos metahidrotermalitos poderia ser explicada pela reação (Winkler 1979):

Ilita $+\mathrm{Al}_{2} \mathrm{O}_{5}=>$ Muscovita + Quartzo $+\mathrm{H}_{2} \mathrm{O}$

onde a ilita representaria a fração micácea potássica, geralmente referida, em produtos de alteração hidrotermal, como sericita ou hidromica (Guven 1988). Contudo, para gerar termos mais sódicos tais como paragonita, seria necessária uma reação do tipo (Winkler 1979):

Na-montmorilonita + Albita $=>$ Paragonita + Quartzo

mas nenhuma das reações explica a pobreza ou ausência de quartzo nas rochas estudadas, a menos que o sistema de reações metamórficas tenha resultado em uma subsaturação generalizada em $\mathrm{SiO}_{2}$.

A disposição zonada dos metahidrotermalitos indica que os respectivos protolitos eram mineralogicamente distintos, provavelmente em resposta a gradientes termais e químicos a partir dos condutos. Apesar de não ser necessário invocar 


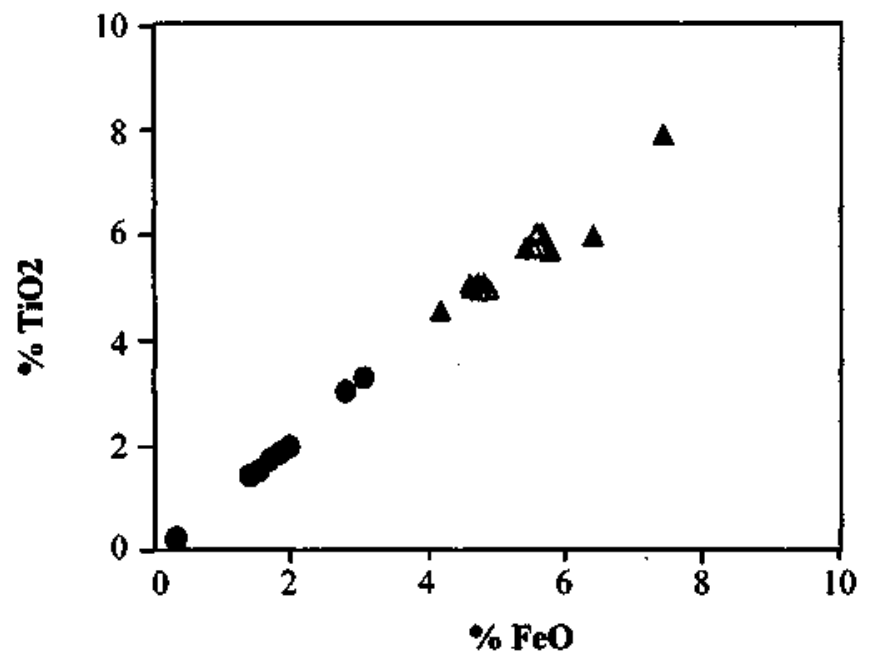

Figura 6-Diagrama $\mathrm{FeO}$ versus $\mathrm{TiO}_{2}$ de hematita das subfacies magnetita (O) e hematita ( $\mathbf{A}$ ) das formaços ferrlferas da Formaçdo Aimbe, mostrando correlacáo linear positiva entre essses elementos e que a hematita da segunda e mais rica em ambos

Figure 6- FeO versus $\mathrm{TiO}_{2}$ diagram for haematite of the magnetite $(\mathrm{O})$ and haernatite (A) sub-facies of the iron formations of the Aimbe Formation, showing the positive linear correlation between these elements and that haematite of the later is richer in both elements than the former

diferenças substanciais de temperatura para explicar os argilo-minerais estimados para os protolitos dos diversos halos, as fases potássicas, mais externas, requerem temperaturas menores que as ferromagnesianas, mais internas, particularmente se a ilita original continha moléculas de bramalita (ilita sódica), como sugem Velde (1985) e Guven (1988).

Os dados petrográficos mostram que a turmalina das paredes dos condutos é primária, $\mathrm{e}^{*} \mathrm{n}$ contraste com a que extensivamente substitui cloritóide, muscovita e magnetita, e que é produto metamórfíco. A coexistência de ambas em domínios justapostos se justifica pela inércia química das paredes monominerálicas dos condutos durante o metamorfismo, em contraste com a reatividade da associação mineral da zona do cloritóide, imediatamente adjacente.

A turmalina hidrotermal pode ser explicada mediante uma reação entre argilominerais ferromagnesianos e fluidos ricos em boro. Borossilicatos como serendibita, harrelsita e reedmergerita, de estabilidade reduzida (Taylor \& Slack 1984), podem ser precursores da turmalina, talvez já formada por diagênese. A turmalina metamórfica, no entanto, pode ser explicada por dois processos. Um utilizaria uma turmalina precursora diagenética e sua recristalização durante o metamorfismo. Outro implicaria em reações com liberação de Boro contido em argilominerais, por aumento de temperatura durante o metamorfismo, e a reação

Clorita $+\mathrm{BO}_{3}=>$ Turmalina

proposta por Henry \& Guidotti (1985) poderia justificar a sua formação e as relações texturais observadas.

O metamorfismo de óxidos de ferro depende, em grande parte, da $\mathrm{f}_{\mathrm{O} 2}$ do sistema (Frost 1991). As paragêneses minerais das diversas zonas de metahidrotermalitos contém magnetita, com ilmenita subordinada. Segundo Melnik (1982) e Frost (1991), um aumento de $\mathrm{f}_{02} \mathrm{em}$ um sistema saturado em magnetita, na presença de ilmenita, conduz à formação de hematita. A ausência de hematita nos hidrotermalitos sugere que a presença de magnetita e ilmenita pode ser devida a flutuações de $\mathrm{f}_{02}$ por despressurização durante as descargas hidrotermais, sendo portanto primárias, ou a $\mathrm{f}_{02}$ do sistema foi mantida abaixo do buffer hematita/magnetita + ilmenita durante o metamorfismo, favorecendo as últimas, em virtude da simultânea formação de cloritóide e clorita. Entretanto, em ambos casos há incertezas. No primeiro, a incerteza reside na própria natureza das espécies minerais precursoras das fases metamórficas, ao que se soma o amplo intervalo de temperatura de estabilidade do sistema hematita/ magnetita + ilmenita, inibindo a definição da temperatura e da $\mathrm{f}_{02}$ das soluções hidrotermais. No segundo caso, a incerteza reside nas condições termodinâmicas, experimentalmente desconhecidas, que controlam a estabilidade de magnetita e ilmenita durante o metamorfismo de um sistema que também estabilizou clorita, cloritóide e muscovita.

Formações Ferríferas $\mathrm{Na}$ discussão da petrogênese das formações ferríferas deve-se abordar, separadamente, os níveis com magnetita e/ou hematita e os níveis com muscovita.

NÍVEIS FERRÍFEROS Os níveis ferríferos contém a associação magnetita + hematita, em proporções que variam com a altura estratigráfica nas formações ferríferas. Genericamente, a primeira predomina na metade inferior e, a segunda, na metade superior do pacote. Ilmenita ocorre em traços ao longo da coluna.

A hematita não ocorre como fase inteiramente independente, indicando que em nenhum momento foi ultrapassado o buffer magnetita-hematita (Fig. 7) e que o sistema foi controlado pelo equilíbrio ilmenita-magnetita primárias. A capacidade da estrutura da hematita para acomodar quantidades significativas de Ti e o enriquecimento gradual em Ti no mineral, da subfácies magnetita para a subfácies hematita, indicam que o mesmo foi estabilizado a $\mathrm{f}_{\mathrm{O} 2}$ inferiores ao tampão magnetita-hematita, eliminando a Ti-hematita e mantendo o equilíbrio ao longo do solvus ilmenitamagnetita.

Todavia, a capacidade de oxi-redução não se altera significativamente durante o metamorfismo de formações ferríferas, salvo pequenas flutuações, como exemplifica a Formação Aimbé. Se as subfácies com magnetita e com hematita podem ser explicadas por metamorfismo, então a maior $\mathrm{f}_{\mathrm{O} 2}$ esteve confinada à zona de passagem gradual entre estas. Entretanto, a posição estratigráfica relativa

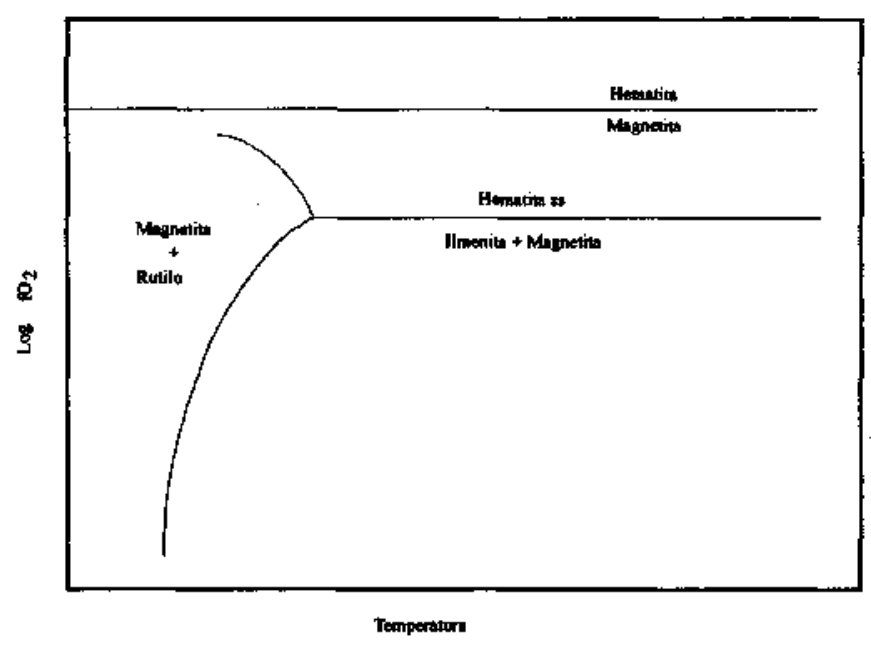

Figura 7 -Diagrama de variação log $\mathrm{fO}_{2}$ versus Temperatura para a faixa de baixa temperatura do sistema $\mathrm{Fe}-\mathrm{Ti}-\mathrm{O}$ (modificado de Frost 1991)

Figure 7 - Variation of $\log \mathrm{fO}_{2}$ with temperature for low temperatures in the system Fe-Ti-O (modified after Frost 1991) 
entre as duas subfácies, a passagem gradual entre ambas e o aumento progressivo das proporções de Ti na hematita da base para o topo das formações ferríferas sugerem que tanto magnetita quanto hematita são primários e que o ambiente deposicional foi progressivamente mais redutor, o que é corroborado pelo contato gradual entre o topo da subfácies hematita e a base da Formação Cabaçal, sobreposta e composta de uma espessa sequência de fillhos carbonosos.

Finalmente, a extensiva martitização da magnetita da Formação Aimbé (Resende 1994), também, é comum em diversas formações ferríferas do tipo Algoma. Floran \& Papike (1978) e Melnik (1982) sugerem que a martitização resulta de variações substanciais na $f_{\mathrm{O} 2}$ durante $\mathrm{o}$ metamorfismo. No entanto, a idêntica oxidação de cristais de magnetita, tanto pré- quanto sin-cinemáticos, indica que a martita é supergênica.

NÍVEIS COM MUSCOVITA A mica branca que ocorre nas formações ferríferas estudadas, ora intersticial aos minerais óxidos de ferro, ora em bandas independentes, constitui o principal problema petrológico destas rochas e não há registro de casos similares na literatura. A ausência de quartzo reflete baixas concentrações de silica durante a deposição e sinaliza condições físico-químicas muito seletivas durante a lixiviação subterrânea ou durante a deposição.

As diferenças geoquímicas entre metahidrotermalitos e formações ferríferas e os contrastes composicionais da muscovita de ambos, opõem-se à hipótese de que o mineral precursor possa ser explicado por uma origem comum. Enquanto a sua presença nos metahidrotermalitos pode ser justificada por argilo-minerais hidrotermais, nas formações ferríferas o mineral precursor da muscovita deve ser de proveniência elástica ou vulcanoclástica.

A presença de mica branca nos metaconglomerados basais da Formação Aimbé e a gradação desses para metafoIhelhos extremamente ricos em muscovita, composicionalmente idêntica à das formações ferríferas, suportam uma origem elástica para o mineral. Dados geoquímicos de elementos maiores, menores, em traço e de Terras Raras das rochas metassedimentares detríticas das Formações São Patricinho e Cabaçal (Jost et al. 1993, Jost et al 1995), mostram que a composição dos respectivos protolitos pode ser justificada por uma mistura de detritos provenientes de basaltos, komatiítos e rochas félsicas. Este modelo, no entanto, não compatibiliza a abundância de muscovita, a ausência de quartzo e as proporções insignificantes de $\mathrm{MgO}$, $\mathrm{CaO}, \mathrm{Cr}$ e Ni dos níveis de muscovita das formações ferríferas, em contraste com a abundância de clorita e quartzo e os elevados teores daqueles óxidos e elementos nas rochas metassedimentares detríticos sub- e sobrejacentes à Formação Aimbé.

Os teores elevados de $\mathrm{BaO}$ e $\mathrm{Na}_{2} \mathrm{O}$ sugerem uma relação da muscovita com feldspatos. Já a assinatura de ETR dos níveis onde o mineral predomina se assemelha com a de trondhjemitos (Resende 1994, Resende \& Jost 1994). Estas observações sugerem que o mineral deriva, provavelmente, da recristalização metamórfica quer de cinza vulcânica, muito rica em uma componente feldspática, ou de um argilomineral do grupo da illita resultante da alteração de centros vulcânicos conteporâneos à deposição da Formação Aimbé. Contudo, até o presente, não há registro de rochas vulcânicas félsicas no contexto estratigráfico do Grupo Guarinos (Jost et al 1993), o que dificulta associá-la ao vulcanismo, exceto, talvez, com centros vulcânicos distais, o que justificaria a sua interpretação como de derivação cinerítica.

Qualquer que seja a origem do mineral precursor da muscovita, é necessário conceber um fracionamento entre detritos grossos e finos durante o transporte, com deposição dos últimos em sítios distais, como verdadeiros argilitos, sem quartzo.

CONCLUSÕES Formações ferríferas e lentes de metahidrotermalitos da Formação Aimbé mostram relações mútuas que não podem ser considerados como acidentais, mas que permitem interpretar as primeiras como exalitos resultantes de emanações que alcançaram a superfície ao longo de zonas preferenciais de descarga, fossilizados nos metahidrotermalitos. $\mathrm{O}$ engaste das lentes de metahidrotermalitos em metassedimentos da Formação São Patricinho e em metabasaltos da Formação Serra Azul indica que estas unidades alojaram as células do sistema hidrotermal, as zonas de descarga e foram o substrato da deposição da Formação Aimbé. A parcial interdigitação lateral dos metahidrotermalitos com formações ferríferas indica que os centros de descarga eram topograficamente elevados.

As paragêneses minerais das lentes de metahidrotermalitos, caracterizadas pela abundância de aluminossilicatos, exceto muscovita, ricos em ferro, são composicionalmente compatíveis com as observadas nas formações ferríferas, reforçando uma gênese comum para ambas. Apesar da gênese comum, metahidrotermalitos e formações ferríferas se explicam mediante protolitos distintos.

A composição das espécies minerais das diversas zonas dos metahidrotermalitos podem ser explicadas, na ausência de quartzo, por reações metamórficas envolvendo proporções variadas de caolinita, diásporo, magnetita, pírofilita, illita, Na-montmorillonita, albita e mesmo turmalina primária. Contudo, a muscovita das formações ferríferas é composicionalmente incompatível com a dos metahidrotermalitos, sugerindo que o seu material precursor não tem, provavelmente, ligação com as exalações. Os seus teores em $\mathrm{K}$ e Ba apontam para materiais mais próximos da composição de feldspatos, provavelmente relacionada com o aporte de cinza vulcânica, simultânea à precipitação dos óxidos e/ou hidróxidos de ferro precursores da magnetita e hematita destas.

Agradecimentos Ao Conselho Nacional de Desenvolvimento Científico e Tecnológico - CNPq pelos recursos financeiros para desenvolvimento desse projeto como parte da Dissertação de Mestrado do autor sênior e pelas Bolsas de Mestrado e de Pesquisa dos autores.

\section{REFERÊNCIAS BIBLIOGRÁFICA}

BANFIELD, J.F.; KARABINOS, P. \& VEBLEN, D.R. 1989. Transmission Electron Microscopy of Chloritoid: Intergrow with Sheet Silicates and Reactions in Metapelites. Amer. Mineralogist, 74:549-564.

CARITAT, P.; HUTCHEON, I. \& WALSHE, J.L. 1993. Chlorite Geothermometry: A Review. Clay and Clay Minerals, 41:219-239.

DEER, W.A.; HOWIE, R.A. \& ZUSSMAN, J. 1992. An Introduction to the Rock-Forming Minerals. New York, Longman Scientific \& Technical, 696p.

DANNI, J.C.M \& RIBEIRO, C.C. .1978. Caracterização estratigráfica da seqüência vulcano-sedimentar de Pilar de Goiás e de Guarinos, Goiás. In: CONGRESSO BRASILEIRO DE GEOLOGIA, 30, Recife, 1978 , Anais... Recife, SBG, 2:252-269
DANNI, J.C.M., JOST, H.; WINGE, M. \& ANDRADE, G.F. .1986. Aspectos da evolução dos terrenos granito-greenstone: exemplo da região de Hidrolina, Goiás. In: CONGRESSO BRASILEIRO DE GEOLOGIA, 34, Goiânia, 1986, A«a/j...Goiânia, SBG, 2:570-584

FLORAN, R.J. \& PAPIKE, J.J. 1978. Mineralogy and Petrology of the Gunflint Iron Formation, Minnesota-Ontario: Correlation of Compositional and Assemblage Variations at low to Moderate Grade. Jour. Petr., 19:215-288.

FOSTER, M.D. 1962. Interpretation of the Composition and a Classification of the Chlorites. U.S. Geol. Surv. Prof. Paper 414 A, 33p.

FROST, B.R. 1991. Stability of Oxide Minerals in Metamorphic Rocks. Reviews in Mineralogy, Mineral. Soc. Am., 21:469-486. 
GANGULY, J. 1969. Chloritoid Stability and Related Parageneses: Theory, Experiments and Applications. Amer. Journ. Sei. 267:910-944.

GUVEN, N. 1988. Smectites: Reviews in Mineralogy, Mineral. Soe. Am., 19:497-559

HENRY, D.J. \& GUIDOTTI, C.V. 1985. Tourmaline as a Petrogenetic Indicator Mineral: an Example from the Staurolite-Grade Metapelites of NW Maine. Amer. Mineral., 70:1-15.

HILLIER, S. 1993. Origin, Diagenesis and Mineralogy of Chlorites Minerals in Devonian Lacustrine Mudrocks, Ordovician Basin, Scotland. Clay and Clay Minerals, 41:240-259.

JOST, H. \& OLIVEIRA, A.M. 1991. Stratigraphy of the Greenstone belt, Crixás region, Central Brazil. Jour, of South Amer. Earth Sci. 4(3):201-204.

JOST, H.; KUYUMJIAN, R.M. \& SILVA.C.A. .1993. Características Geoquímicas e a Proveniência dos Metassedimentos Arqueanos do Grupo Guarinos, GO. CONGRESSO BRASILEIRO DE GEOQUIMICA, 4, Brasília, 1993, Resumos Expandidos, p. 109-111.

JOST, H; RESENDE, M.G. \& SILVA, C.A. 1994. Redefinição Estratigráfica e Litológica da Formação Aimbé, Grupo Guarimos, GO. SIMP. GEOL. CENTRO-OESTE, 4, Brasilia, 1994, Resumos Expandidos, p. 11-14.

JOST, H.; FIGUEIREDO, A.M.G. \& FERREIRA, A.V. 1995. - Elementos em traço e a proveniência elástica na transição de ambiente euxênico para turbidítico em metassedimentos do greenstone belt de Guarinos, Goiás, in SBGq, V Cong. Brasileiro de Geoquímica, Niterói, 1995. Anais..., CD-ROM, 4 pgs.

JOST, H ; VARGAS, MC ; GUGELMIN, V \& OLIVEIRA, S.R.M 1989. Seqüência Morro Escuro: uma nova unidade estratigráfica do Arqueano/ Proterozóico Inferior na região de Crixás, Estado de Goiás. Rev. Bras. Geoc., 19(3):283-289
MEL'NIK, Y.P. 1982. Precambrian Banded Iron-Formation: Physicochemical Conditions of Formation. Amsterdam, Elsevier, $31 \mathrm{Op.}$

RESENDE, M.G. 1994. Geoquímica e Petrologia da Formação Aimbé, Grupo Guarinos, Goiás. Dissertação de Mestrado, Instituto de Geociências, Universidade de Brasília, 128p.

RESENDE, M.G. \& JOST, H. 1994. Geoquímica e Química Mineral dos Litotipos da Formação Aimbé, Grupo Guarinos, GO. In: SIMP. BRAS. CENTRO-OESTE, 4, Brasília, 1994, Resumos Expandidos, p. 15-17.

RESENDE, M.G.; JOST, H.; SILVA, C.A.; VIEIRA, A.C. \& DA SILVA, C.M. 1993. Aspectos Geoquímicos dos Exalitos da Formação Aimbé, Grupo Guarinos, GO. In: CONGRESSO BRASILEIRO DE GEOQUÍMICA, 4, Brasília, 1994, Resumos Expandidos, p.133-135.

ROSEMBERG, P.E. \& FOIT, F.F. 1985. Tourmaline Solid Solutions in the System MgO-Al $\mathrm{O}_{3}-\mathrm{SiO}_{2}-\mathrm{B}_{2} \mathrm{O}_{3}-\mathrm{H}_{2} \mathrm{O}$. Amer. Mineral., 70:1217-1223.

SABÓIA, L.A. .1979. Os greenstone belts de Crixás e Goiás, Go. SBG, Núcleo Centro-oeste,fio/e//m Informativo 9 , Goiânia, 43-72

TAYLOR, B.E \& SLACK, J.F. 1984. Tourmalines from AppalachianCaledonian Massive Sulfide Deposits: Textural, Chemical and Isotopic Relationship. Economic Geology, 79:1703-1726.

VELDE, B. 1985. Clay Minerals - A Physico-chemical Explanation of their Occurrence: Economic Geology. Amsterdam, Elsevier, 427 p.

WINKLER, H.G.F. 1979. Petrogênese das Rochas Metamórficas. Edgard Blücher,UFRGS,256p.

MANUSCRITO A830

Recebido em 24 de fevereiro de 1995 Revisão do autor em 06 de dezembro de 1995 Revisão aceita em 11 de dezembro de 1995 